\title{
Biodiversity of Enterobacteriaceae on masin (fermented sauce) from Sumbawa, West Nusa Tenggara, Indonesia
}

\author{
BASO MANGUNTUNGI ${ }^{1, \bullet}$, DINAR S. SAPUTRI ${ }^{2, \bullet \bullet}$, CHAIRUL A. AFGANI ${ }^{3}$, APON Z. MUSTOPA ${ }^{4}$, \\ FATIMAH ${ }^{5}$, AMIRIN KUSMIRAN ${ }^{6}$ \\ ${ }^{1}$ Department of Biotechnology, Faculty of Biotechnology, Universitas Teknologi Sumbawa. Jl. Raya Olat Maras, Moyo Hulu, Sumbawa 84371, West \\ Nusa Tenggara, Indonesia. Tel./fax.: +62-371-2629009, `email: baso.manguntungi@uts.ac.id \\ ${ }^{2}$ Department of Applied Chemistry, Chaoyang University of Technology. 168, Jifeng E. Rd., Wufeng District, Taichung, 41349 Taiwan, R.O.C. Tel./fax.: \\ +886-4-23323000/+886-4-23329898, vvemail: s10832905@gm.cyut.edu.tw \\ ${ }^{3}$ Department of Agricultural Product Technology, Faculty of Agricultural Technology, Universitas Teknologi Sumbawa. Jl. Raya Olat Maras, Moyo \\ Hulu, Sumbawa 84371, West Nusa Tenggara, Indonesia \\ ${ }^{4}$ Research Center for Biotechnology, Indonesian Institute of Sciences. Jl. Raya Bogor Km 46, Cibinong, Bogor 16911, West Java, Indonesia \\ ${ }^{5}$ Indonesian Center for Agricultural Biotechnology and Genetic Resources Research and Development. Jl. Tentara Pelajar No. 3A, Cimanggu, Bogor \\ 16111, West Java, Indonesia \\ ${ }^{6}$ Department of Science and Technology, Universitas Islam Negeri Alauddin Makassar. J1. Sultan Alauddin No. 63, Makassar (Kampus I), Gowa 92113, \\ South Sulawesi, Indonesia
}

Manuscript received: 18 December 2019. Revision accepted: 9 February 2020

\begin{abstract}
Manguntungi B, Saputri DS, Afgani CA, Mustopa AZ, Fatimah, Kusmiran A. 2020. Biodiversity of Enterobacteriaceae on masin (fermented sauce) from Sumbawa, West Nusa Tenggara, Indonesia. Biodiversitas 21: 1001-1006. Masin is fermented sauce originating from Sumbawa, West Nusa Tenggara which is made from raw shrimp with the addition of tamarind, salt, and fingerroot (Boesenbergia pandurata) flower. The study aimed to determine the biodiversity of pathogenic bacteria, especially Enterobacteriaceae family in Masin. The methods used in this study were isolation of bacteria using MRS media with modified NaCl concentration (1-12\%) and molecular identification by using PCR-RAPD (randomly amplified polymorphic DNA) analysis and 16S ribosomal RNA-based sequencing analysis. The characteristics of bacteria that were successfully isolated on media with various concentrations of salt were round, milky white, and formed a flat edge with convex elevation in each colony. The highest bacterial population was $29.65 \times 10^{6}$ $\mathrm{CFU} / \mathrm{g}$ in $\mathrm{MRS}+\mathrm{NaCl} 7 \%$ treatment. From 48 selected isolates that morphologically close to Enterobacteriaceae family, 5 isolates were chosen for sequencing analysis. Based on the phylogenetic analyses, isolate 01 had a close kinship with Leclercia adecarboxylata, isolate 11 had a close kinship with Citrobacter freundii, isolate 33 had a close kinship with Enterobacter cloacae, isolate 40 had a close kinship with Pantoea agglomerans and isolate 46 had a close kinship with Enterobacter ludwigii.
\end{abstract}

Keywords: Biodiversity, Enterobacteriaceae, masin, Sumbawa

\section{INTRODUCTION}

Fermented foods are the mixture of microorganisms that either present as natural indigenous microbiota in raw plants or animal substrates, utensils, containers, environment or added starter culture(s) containing functional microorganisms that modify the substrates into edible products that are organoleptically, culturally and socially acceptable to the consumers. During fermentation, microorganisms convert chemical composition of raw materials, which enriches the nutritional value that delivers health benefits to the consumers (Tamang et al. 2016).

While food fermentation is generally expected to improve food safety, it is not an entirely risk-free process. The risks of contamination in fermented food increase when spontaneous fermentation is used instead of well-defined starter cultures. In a fermentation with questionable raw material sources and fermentation conditions, potential pathogens and toxic compounds can be developed (Lavefve et al. 2019). Biologic hazards can occur during fermentation as a result of microbial metabolism, like biogenic amines in sauerkraut fermentation (Medina et al. 2015).
Functional properties of microorganisms in fermented foods include probiotics and antimicrobial properties, antioxidant activity, peptide production, fibrinolytic activity, degradation of antinutritive compounds which produces poly-glutamic acid that incurs desirable organoleptic properties to the final fermented product. (Lavefve et al. 2019). Lactic acid bacteria (LAB) play an important role in food preservation and fermentation processes by lowering the $\mathrm{pH}$ and producing bacteriocins, which prevent the growth of pathogenic and spoilage microorganisms. Lactobacilli are also "friendly" bacteria that commonly live in human digestive systems without causing disease (Wu et al. 2018). Biodiversity of lactic acid bacteria in masin is still being studied.

Research by Chrun et al. (2017) found that $24 \%$ of 68 samples fermented vegetables in Cambodia's local market were contaminated by Enterobacter spp. Contamination by Enterobacter also found in traditional fermented fish products from Ivory Coast, namely adjuvant (Koffi-Nevry and Koussemon 2012). Adjuvant was dominated by $9.72 \%$ Enterobacter spp. contamination from 38 gram-negative bacterial isolates. Pathogenic bacteria are widespread in the 
environment, improper handling and nonhygienic conditions during the process can cause contamination (Clarence et al. 2009).

Enterobacter is a gram-negative bacterium, facultative anaerobes, rod-shaped with rounded edges, does not form spores, and belongs to the family Enterobacteriaceae (Munez et al. 2012; Motarjemi et al. 2014). Enterobacter is an opportunistic pathogen that quickly adjusts metabolism and physiology to external conditions and environmental stress. This bacterium causes antibiotic resistance (DavinRegli and Pages 2015). Enterobacter is dangerous pathogens, e.g. Enterobacter aerogenes which causes urinary tract infections (Edlin et al. 2013), respiratory disorders, and drug resistance (Karlowsky et al. 2013). Meanwhile, Enterobacter cloacae cause ESBL-bacteremia (broadspectrum $\beta$-lactamase-producing bacteria) (Buckle 2015).

Sumbawa has a traditional fermented sauce called Masin that is made of shrimp paste, chili, turmeric flower, and herbs mixed with some spices. These ingredients were blended and fermented spontaneously. The traditional fermentation is an uncontrolled process which can result in inconsistent final products that may harbor undesirable microbial growth. Poor hygienic conditions in which they are processed may lead to the introduction of other microorganisms including pathogenic ones. In the spontaneous fermentation ecosystem, contribution of microbial groups to spoilage mainly depends on their living conditions and their competitions (Li et al. 2014; Medina et al. 2015; Capozzi et al. 2017; Mwizerwa et al. 2018).

The aim of the study is to determine the type of pathogenic bacteria that interfere fermentation process of masin. Pathogen contamination such as Enterobacter is substantial, given the large population of bacteria in air and water. The presence of pathogenic bacteria in fermented foods can be traced by isolating the bacteria and sequencing of 16S RNA gene to analyze bacterial diversity and population dynamics during the fermentation process (Astudillo-Melgar et al. 2019).

\section{MATERIALS AND METHODS}

\section{Study area}

Sumbawa is one of the districts in West Nusa Tenggara (NTB), Indonesia. Sumbawa is famous for masin, one of its local fermented products. The study began from June to August 2019. The research was conducted at the Laboratory of Applied Genetic Engineering and Protein Design, Research Center for Biotechnology, Indonesian Institute of Sciences, Bogor, West Java, Indonesia.

\section{Procedures}

\section{Sample preparation}

Masin samples were obtained from Empang Subdistrict, Sumbawa District, West Nusa Tenggara, Indonesia. Masin is stored at $4^{\circ} \mathrm{C}$ to avoid damage.

\section{Isolation of bacteria from masin}

Isolation was carried out by suspending $100 \mathrm{mg}$ of salt sauce in $5 \mathrm{~mL}$ of MRS Broth media with various concentrations of salt was and incubated for 24 hours at $37^{\circ} \mathrm{C}$. Salt was used in MRS broth media to simulate masin salty conditions. After incubation, dilution was carried out by suspending $100 \mu \mathrm{L}$ of culture from MRS broth with 900 $\mu \mathrm{L}$ of $\mathrm{NaCl} 0.85 \%$. Dilution was carried out in stages until dilution $10^{-7}$. A total of $100 \mu \mathrm{L}$ from $10^{-5}, 10^{-6}$ and $10^{-7}$ dilutions were taken and spread on agar with 1-12\% $\mathrm{NaCl}$. The culture was incubated for 24 hours at $37^{\circ} \mathrm{C}$. A single colony that grew was then subcultured on MRS Broth media for genomic DNA isolation.

\section{Genomic DNA isolation}

One and a half milliliters $(1.5 \mathrm{~mL})$ of liquid culture was taken in Eppendorf and centrifuged at $12000 \mathrm{rpm}$ for 10 minutes at $4^{\circ} \mathrm{C}$. Supernatant was removed, $1.5 \mathrm{~mL}$ of liquid culture was added and re-centrifuged at $6000 \mathrm{rpm}$ for 10 minutes at $4^{\circ} \mathrm{C}$. Supernatant was removed. The resulting pellet was added with $500 \mu \mathrm{L}$ TE buffer and $40 \mu \mathrm{L}$ Lysozyme $(60 \mathrm{mg} / \mathrm{mL})$ and then incubated at $37^{\circ} \mathrm{C}$ for 1 hour. After incubation, $200 \mu \mathrm{L} 10 \%$ SDS, $100 \mu \mathrm{L} 5 \mathrm{M}$ $\mathrm{NaCl}, 80 \mu \mathrm{L} \mathrm{10 \%} \mathrm{CTAB}$ was added to Eppendorf and then incubated $60^{\circ} \mathrm{C}$ for 30 minutes (turn Eppendorf every 10 minutes). $1 \mathrm{~mL}$ chloroform was added and centrifuged at $13000 \mathrm{rpm}$ for 10 minutes at $4^{\circ} \mathrm{C}$. The supernatant was transferred to new Eppendorf and added with 0.6 volume isopropanol, incubated for 2 hours at $-20^{\circ} \mathrm{C}$ and recentrifuged at $13000 \mathrm{rpm}$ at $4^{\circ} \mathrm{C}$ for 10 minutes. Supernatant was removed and pellets were added with 1 $\mathrm{mL}$ of $70 \%$ ethanol and centrifuged at $13000 \mathrm{rpm}$ for 10 minutes, at $4^{\circ} \mathrm{C}$. The supernatant was discarded and the pellets were dried overnight. $30 \mu \mathrm{L} \mathrm{ddH}_{2} \mathrm{O}$ and $5 \mu$ LRNAse $(1 \mathrm{mg} / \mathrm{mL})$ were added to the pellets and incubated at $37^{\circ} \mathrm{C}$ for 1 hour. The DNA isolates were stored at $-4^{\circ} \mathrm{C}$ and analyzed with gel electrophoresis on $2 \%(w / v)$ agarose gel using 1 xTAE buffer. The gel was stained in a solution of ethidium bromide and scanned using UV transilluminator (Mustopa 2013).

\section{PCR-RAPD bacteria isolates from masin}

RAPD is a method used to identify the level of genetic diversity in Lactic acid bacteria (LAB). The buffer solution

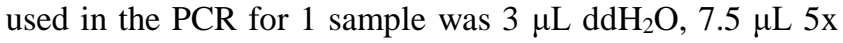
My Taq (Bioline), $1.5 \mu \mathrm{L}$ primers and $3 \mu \mathrm{L}$ DNA templates (LAB DNA Genome) so that the overall total was $15 \mu \mathrm{L}$. The primary used is GTG5. The PCR method performed using the GTG5 primer (5'-GTGGTGGTGGTGGTG-3 ') was previously described by Gevers et al. (2001). The cycling program consisted of 1 cycle of $95{ }^{\circ} \mathrm{C}$ for $7 \mathrm{~min}$.; 30 cycles of $95{ }^{\circ} \mathrm{C}$ for $1 \mathrm{~min}$., $55^{\circ} \mathrm{C}$ for $1 \mathrm{~min}$., and $65^{\circ} \mathrm{C}$ for $8 \mathrm{~min}$.; and 1 cycle of $65^{\circ} \mathrm{C}$ for $16 \mathrm{~min}$. PCR products were analyzed by gel electrophoresis on $2 \%(w / v)$ agarose gel using 1 x TAE buffer. The gel was stained in a solution of ethidium bromide and viewed using UV transilluminator (Chao et al. 2008).

\section{S rRNA PCR analysis and sequencing analysis}

LAB strains found in Masin sauce were analyzed using a 16S rRNA universal primer. The primary sequences used were primers 8F (5'-AGAGTTTGATCATGGCTCAG-3') and primers 16R (5' AAGGAGGTGATCCAACCGCA-3'). 
Positions 1541 to 1522 bp are used to amplify the overall fragment length of 16S rRNA bacteria (Chao et al. 2008). The buffer solution used in PCR includes $\mathrm{ddH}_{2} \mathrm{O} 38.5 \mu \mathrm{L}$, $5 \times$ MyTaq Green $7.5 \mu \mathrm{L}, 8 \mathrm{~F} 1 \mu \mathrm{L}$ primers, $16 \mathrm{R} 1 \mu \mathrm{L}$ primers, DNA templates (DNA genome LAB) $2 \mu \mathrm{L}$ so that the overall total is $50 \mu \mathrm{L}$. The PCR conditions were $96{ }^{\circ} \mathrm{C}$ for 5 min.; 35 cycles consisting of $96{ }^{\circ} \mathrm{C}$ for $1 \mathrm{~min}$., $55^{\circ} \mathrm{C}$ for $3 \mathrm{~min}$., and $72{ }^{\circ} \mathrm{C}$ for $1 \mathrm{~min}$.; and $72{ }^{\circ} \mathrm{C}$ for $7 \mathrm{~min}$. The PCR products were subjected to electrophoresis gel on $1 \%$ agarose gel, followed by ethidium bromide staining. Sequencing results were analyzed using the Basic Local Alignment Search Tool (BLAST) in the NCBI and MegaX programs (Chao et al. 2008).

\section{RESULTS AND DISCUSSION}

\section{Bacterial isolation from masin}

Bacteria originating from spontaneous fermentation of the Masin product was successfully isolated. Shape of the colony was round, milky white in color, and formed flat edge with convex elevation in each colony.

The bacterial population isolated in Masin using MRS media with different physiological salt concentrations is presented in Table 1. The physiological salt tolerance at concentrations of 4 to $8 \%$ gives a significant result on the number of bacteria. The highest number of bacterial colonies was found in the treatment of MRS $+\mathrm{NaCl} 7 \%$ of 29.65 x $106 \mathrm{CFU} / \mathrm{g}$.

\section{PCR-RAPD bacteria isolates from masin}

Total of 48 isolates that have different morphology were then selected using PCR-RAPD to distinguish genotypes that produce different phenotypes in a species. Based on the PCR-RAPD band pattern (Figure 1) and the Phylogeny Tree (Figure 2) 5 isolates of different polymorphisms were obtained, namely isolates $46,1,33$, 40 and 11.

\section{Phylogeny trees}

The phylogenetic tree topology from PCR-RAPD showed two main clades (Figure 2). The first clade has two subgroups with isolate codes $31,38,40$, and 43 as internal points for the first subclass namely isolates with codes 1,2 , $3,13,14,17,18,21,22,23,24,25,26,27,29,36.45$, and 47. Meanwhile, for the second subclass, they are isolates with codes 6, 7, and 42. The first and second subclass isolate groups have a close kinship.

The second clade consists of two subclasses, each of which is divided into two groups. The first subclass consists of two branches. The first branch is isolated with code $4,8,9,15,19,20,28,30,33,34,35,37,39,41,48$, which is closely related to the second branch, isolate with code 44. The second subclass also consists of two branches. The first branch, isolates with codes 16 and 32 are closely related to the second branch, isolates with codes 10 and 46. The ancestors of the isolates are from ancestors with two branches. The first branch of isolates has the codes 5 and 12, while the second branch is isolated code 11 which is out-group. Based on the phylogenetic tree, in each branch of the two clades, one isolate representing each branch in each clade was taken and then an analysis of $16 \mathrm{~S}$ RNA molecular identification was performed.

Table 1. The number of bacteria growing on MRS media with different $\mathrm{NaCl}$ concentrations

\begin{tabular}{lcc}
\hline Media treatment & Isolate code & CFU/g (10 $\mathbf{6})$ \\
\hline MRS + NaCl 1\% & $1-4$ & 3.65 \\
MRS + NaCl 2\% & $5-8$ & 4.85 \\
MRS + NaCl 3\% & $9-12$ & 12.36 \\
MRS + NaCl 4\% & $13-16$ & 20.24 \\
MRS + NaCl 5\% & $17-20$ & 27.66 \\
MRS + NaCl 6\% & $21-24$ & 28.20 \\
MRS + NaCl 7\% & $25-28$ & 29.65 \\
MRS + NaCl 8\% & $29-32$ & 21.34 \\
MRS + NaCl 9\% & $33-36$ & 18.65 \\
MRS + NaCl 10\% & $37-40$ & 13.25 \\
MRS + NaCl 11\% & $41-44$ & 8.40 \\
MRS + NaCl 12\% & $45-48$ & 2.10 \\
\hline
\end{tabular}
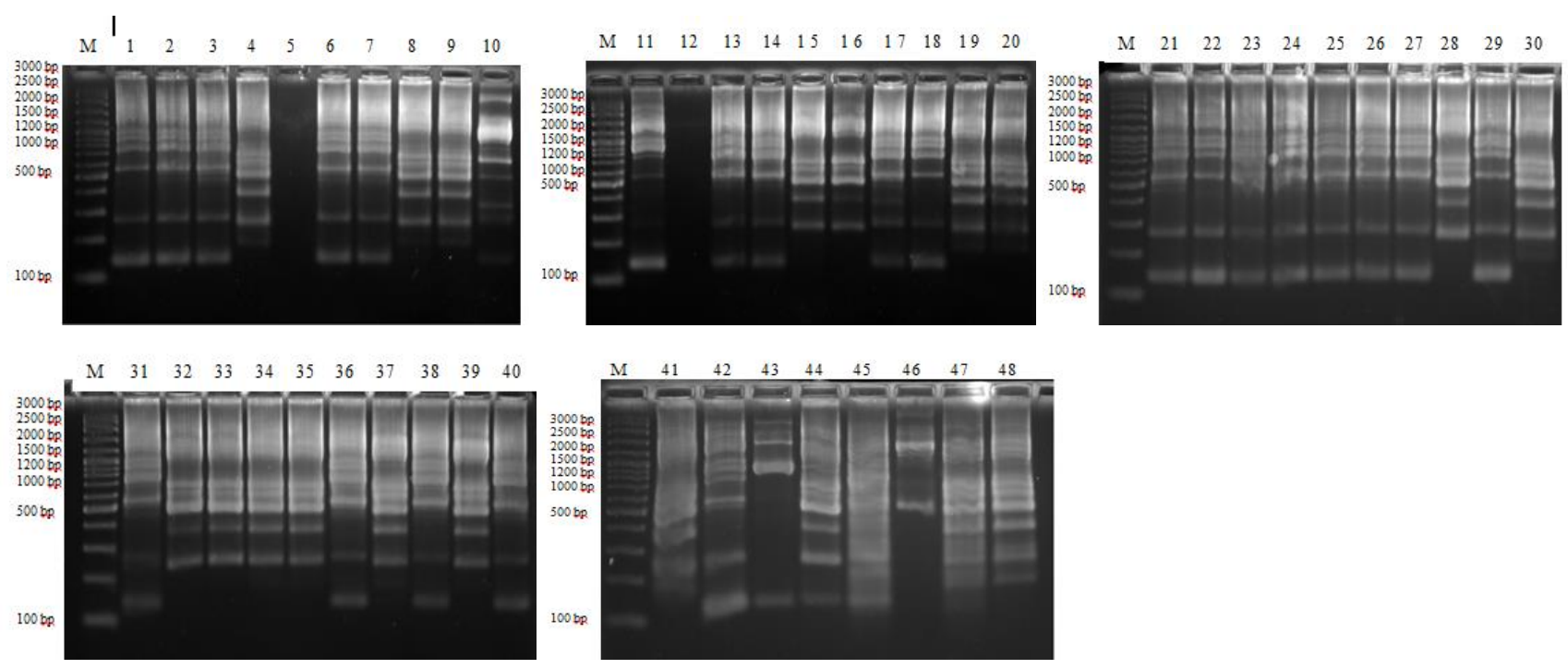

Figure 1. Visualization of PCR-RAPD band pattern of bacteria isolate code 1 to 48 Isolates 


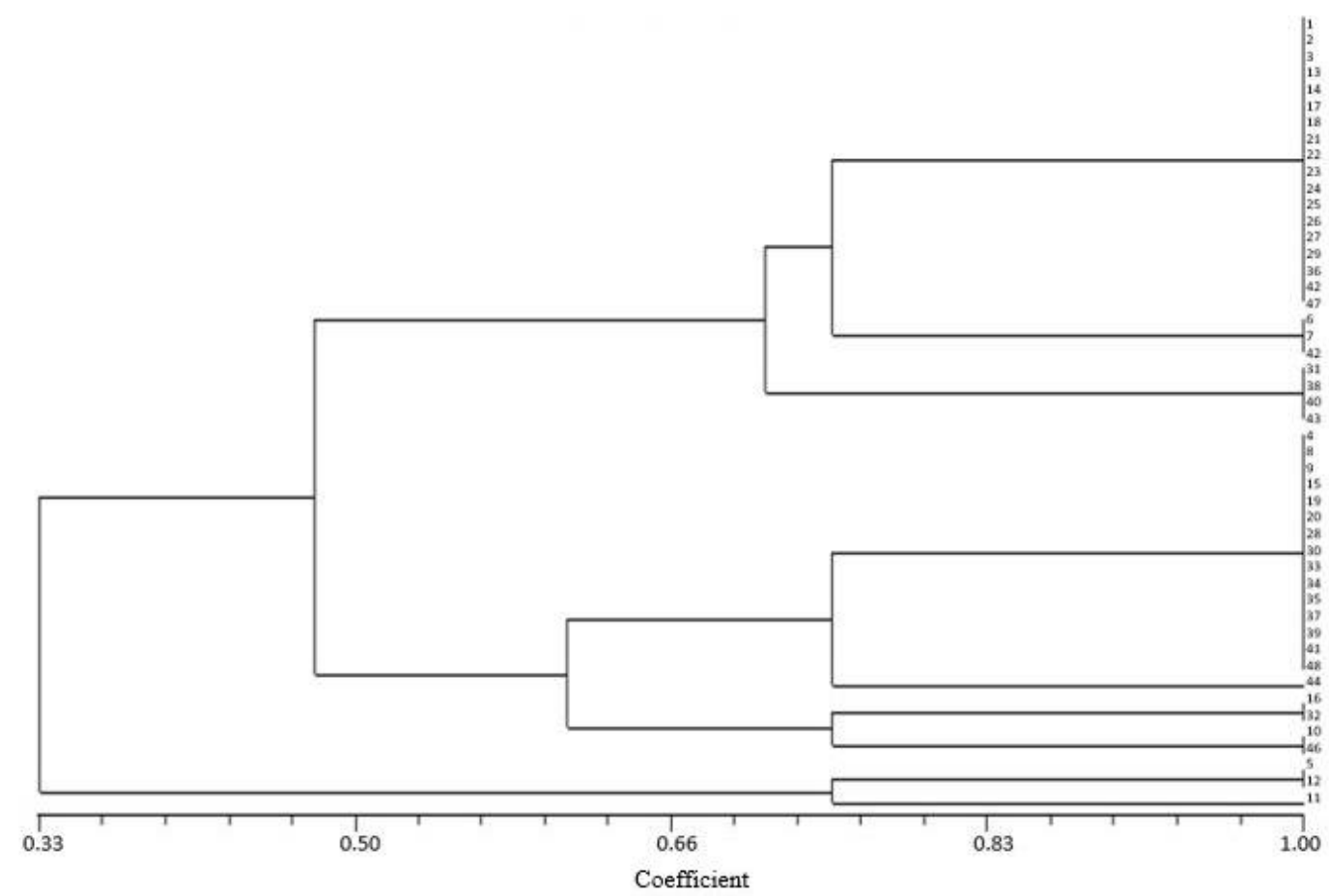

Figure 2. PCR-RAPD phylogenetic tree

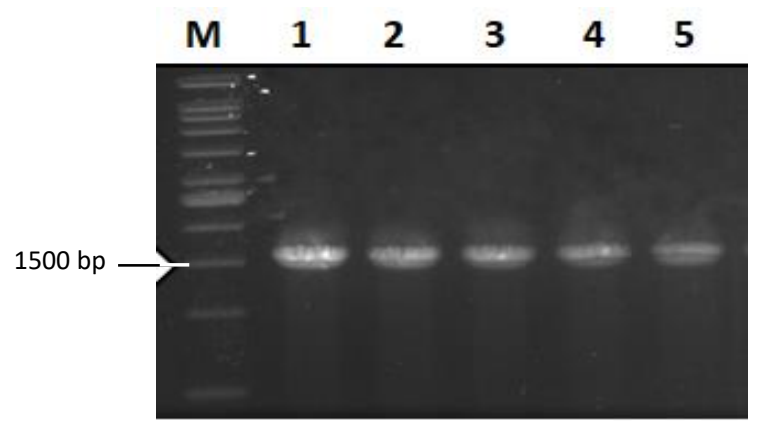

Figure 3. Visualization of the $16 \mathrm{~S}$ rRNA molecular identification band

Table 2. The results of 16S rRNA molecular identification

\begin{tabular}{lllc}
\hline $\begin{array}{c}\text { Isolates } \\
\text { code }\end{array}$ & Species & Identity & $\begin{array}{c}\text { Accession } \\
\text { number }\end{array}$ \\
\hline 46 & Enterobacter ludwigii & $99.45 \%$ & NR_042349.1 \\
1 & Leclercia adecarboxylata & $99.52 \%$ & NR_104933.1 \\
33 & Enterobacter cloacae & $98.90 \%$ & NR_044978.1 \\
40 & Pantoea agglomerans & $99.45 \%$ & NR_041978.1 \\
11 & Citrobacter freundii & $98.08 \%$ & NR_028894.1 \\
\hline
\end{tabular}

\section{Sequencing analysis}

Analysis of the molecular identification of $16 \mathrm{~S}$ rRNA was carried out on 5 isolates that had different polymorphisms based on banding patterns from the results of PCR-RAPD visualization and phylogenetic trees. The species names of each isolate sequencing are shown in Table 2 with the ribbon visualization in Figure 3.

PCR results using primers $8 \mathrm{~F}$ primers (5'AGAGTTTGATCATGGCTCAG-3') and 16R primers (5'-
AAGGAGGTGATCCAACCGCA-3'). Positions 1541 to $1522 \mathrm{bp}$ were used to amplify the full length of bacterial $16 \mathrm{~S}$ rRNA fragment. Electrophoresis results showed clearly visible DNA bands and no mixing bands (ribbons are mixed), then the PCR product was purified. Based on PCR amplification result using $16 \mathrm{~S}$ rRNA primers, a band of $1500 \mathrm{bp}$ was obtained. Then only 5 isolates were selected, namely isolates $46,1,33,40$ and 11 to proceed to a sequence (Table 2).

The results of DNA sequence analysis through the Basic Local Alignment Search Tool (BLAST) database tracking program at the National Center for Biotechnology Information (NCBI), National Institute for Health, USA (www.blast.ncbi.nlm.nih.gov) showed the 16S rRNA coding sequence. Bacterial isolate rRNA has the highest similarity with $16 \mathrm{~S}$ rRNA DNA coding sequences from Enterobacter ludwigii (Isolate Code 46), Leclerciaa decarboxylata (Isolate Code 1), Enterobacter cloacae (Isolate Code 33), Pantoea agglomerans (Isolate Code 40) and Citrobacter freundii(Isolate Code 11).

Analysis of the evolutionary distances to the 5 isolates with phylogenetic trees resulted in a variety of kinship distribution with other isolates (Figure 4). The analysis of kinship was also compared with isolates which were out groups and in groups.

Based on the phylogenetic tree, isolate 01 has a close kinship with Leclercia adecarboxylata with a bootstrap value of 99, isolate 11 had a close kinship with Citrobacter freundii with a bootstrap value of 98.08, isolate 33 had a close kinship with Enterobacter cloacae with a bootstrap value of 98.90 , isolate 40 had a close kinship with Pantoea agglomerans with a bootstrap value of 99.45 and isolate 46 had a close kinship with Enterobacter ludwigii with a bootstrap value of 99.45 . 


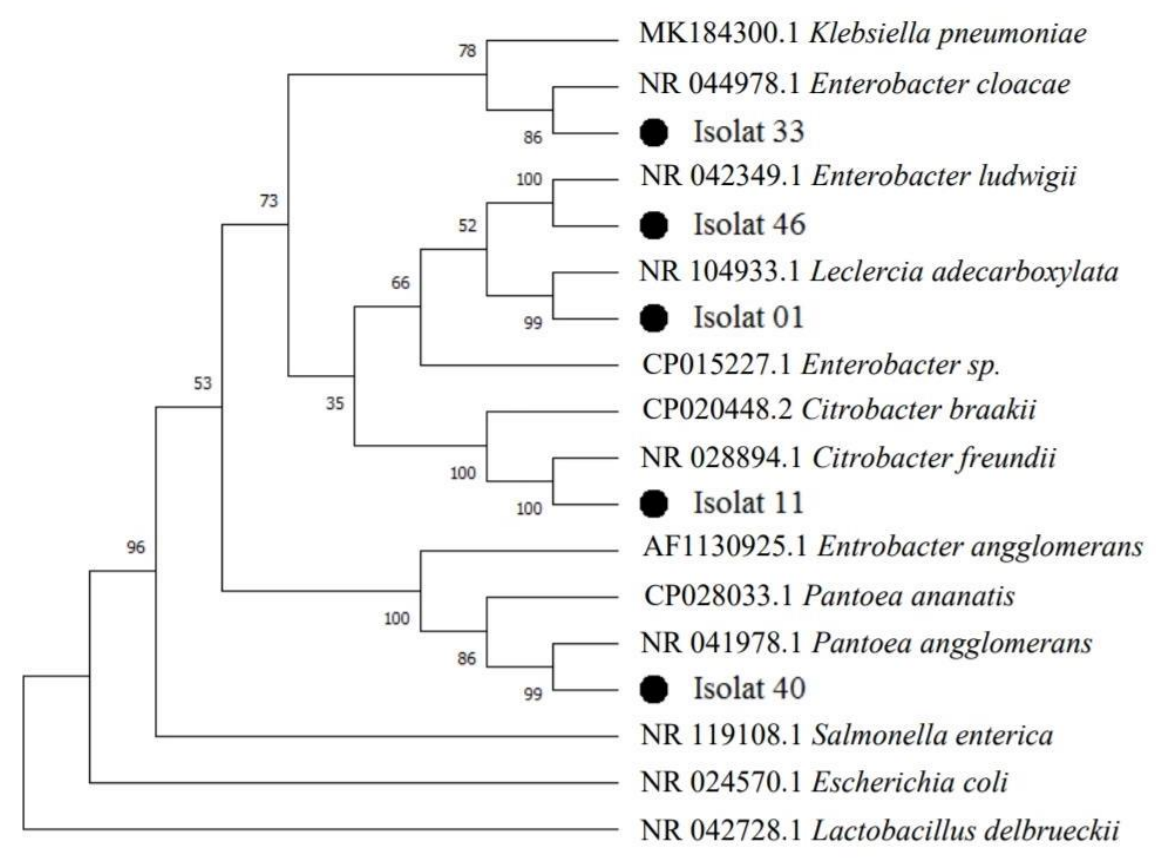

Figure 4. Phylogenetic tree based on 16S rRNA sequence analysis

\section{Discussion}

Masin is fermented sauce derived from raw materials in the form of fish or rebon shrimp added with salt, Javanese tamarind as flavor enhancers, and finger root flowers to neutralize fishy odor caused by shrimp. Salt is used as a preservative and flavor enhancer because it has high osmotic pressure, so it can cause osmosis in shrimp and microorganism cells (Ramzi 2016). Masin is a spontaneous fermentation product that is made without the addition of starter microbes. In rebon shrimp fermentation products, which use high salt levels, it is estimated that microbes are able to grow and develop quite well. The characteristics of the bacterial isolate using de Man Rogosa Sharpe Agar (MRSA) media with modified salt addition obtained are milky white, round and have a slippery surface.

The traditional fermentation is uncontrolled process that can result in inconsistent final products that may harbor undesirable microbial growth. The low $\mathrm{pH}$ of the fermented products and the heat treatment by roasting or cooking would make these products safe for consumption. In any case, unsterile conditions in which they are prepared and took care of may prompt the presentation of pathogenic microorganisms. In the unconstrained fermentation condition, the pathogenic microbial will contribute to spoil the product ( $\mathrm{Li}$ et al. 2014; Medina et al. 2015; Capozzi et al. 2017; Mwizerwa et al. 2018).

There are 48 bacterial isolates that have been successfully isolated from main products. The masin product is the result of bacterial fermentation in shrimp or rebon that takes place spontaneously. The bacterial isolation was carried out on MRS media with different $\mathrm{NaCl}$ concentrations. The treatment of the addition of various different physiological salt concentrations aims to see the tolerance of the bacteria to grow under different salinity conditions. Physiological salts play a role in balancing osmotic pressure between bacterial cells and the medium, and thus they play a role in bacterial growth (Sherman et al. 1922). The effect of physiological salt concentration on the growth of Enterobacteriaceae forms a downward parabolic curve and has a maximum extreme value, in the range of $\mathrm{NaCl}$ with a concentration of 4 to $8 \%$ (Table 1).

Low concentration of $\mathrm{NaCl}$ causes water to enter the cell and vice versa. This has an effect on bacterial viability that decreases at low or high extreme $\mathrm{NaCl}$ concentrations (Table 1). The physiological salt concentration also influences the enzyme activity and the activity of water (Aw) in the cell so that it affects the metabolism of bacterial cells in general (Chandler 1988; Membre and Burlot 1994; Lee et al. 2018). Meanwhile, when the salt added stepwise, growth-promoting effect of Enterobacteriaceae was showed (Botzenhart and Kufferath 1976). Bacteria that succeeded in growing on MRS media with some salt concentrations were then carried out by PCR-RAPD to see differences in genotypes that produce different phenotypes so that they became the basis for selecting bacteria that would later be identified as $16 \mathrm{~S}$ rRNA molecular. PCR-RAPD visualization showed a band pattern with different polymorphisms from 48 isolates. Selected isolates included isolate code 46, 1, 33, 40 and 11. The isolates represented each branch in the phylogenetic tree. However, isolates 1 and 22 were in the same branch with consideration of the visualization of different banding patterns so that for the first branch in the phylogenetic tree two representative isolates were taken. 
The presence of Enterobacteriaceae shows that a failure occurred during processing and their absence indicates that improper hygienic conditions were maintained during the food manufacturing process. Enterobacteriaceae include many pathogens especially Salmonella which is found in meat and its products (especially poultry) and causes food poisoning (Rahman and Othman 2017). Enterobacteriaceae produce biogenic amines cadaverine, histamine, and tyramine in. These compounds which can cause several adverse reactions in the consumers were also found in fermented maize-based products from Western Kenya, blue-veined cheese and spontaneously fermented pickle in Sichuan. However, lactic acid bacteria grow in many foods and quickly decrease the $\mathrm{pH}$ to 3.5 or less and competing microorganisms can no longer grow (Marino et al. 2000; Li et al. 2014; Gardini et al. 2016; Mwizerwa et al. 2018).

\section{ACKNOWLEDGEMENTS}

This research was funded by Ministry of Research, Technology and Higher Education (Indonesia) with Program Pengembangan Teknologi Industri (PPTI) 2019. All facilities were supported by Research Center for Biotechnology, Indonesian Institute of Sciences (LIPI), Bogor, West Java and ICABIOGRAD, Bogor, West Java. The authors would like to thank Leggina Rezzy Vanggy, Khadijah Alliya Fidien, Hanifah Hanjani Putri (Department of Biotechnology, Sumbawa University of Technology), Shasmita Irawan and Adelia Elviantari (Department of Biotechnology, IPB University).

\section{REFERENCES}

Astudillo-Melgar F, Ochoa-Leyva A, Utrilla J, Huerta-Beristain G. 2019. Bacterial diversity and population dynamics during the fermentation of palm wine from Guerrero Mexico. Front Microbiol 10: 1-9.

Buckle J. 2015. Infection. In: Buckle J (ed) Clinical Aromatherapy Essential Oil in Healthcare. Elsevier, United Kingdom.

Botzenhart K, Kufferath R. 1976. On the growth of Enterobacteriaceae, Pseudomonas aeruginosa and Alkaligenes sp. in distilled water, deionized water tap water and mineral salt solution. Zentralblatt fur Bakteriologie, Parasitenkunde, Infektionskrankheiten und Hygiene 163(5-6): 470-485.

Capozzi V, Fragasso M, Romaniello R, Berbegal C, Russo P, Spano G. 2017. Spontaneous food fermentations and potential risks for human health. Fermentation 3: 1-19.

Chandler RE. 1988. The effect of temperature and water activity on microbial growth rate and food spoilage. [Thesis]. University of Tasmania, Tasmania. [Australian]

Chao SH, Tomii Y, Watanabe K, Tsai YC. 2008. Diversity of lactic acid bacteria in fermented brines used to make stinky tofu. Int J Food Microbiol 123: 134-141.

Chrun R, Hosotani Y, Kawasaki S, Inatsu Y. 2017. Microbiological hazard contamination in fermented vegetables sold in local markets in Cambodia. Biocontrol Sci 22: 181-185.

Clarence SY, Obinna CN, Shalom NC. 2009. Assessment of bacteriological quality of ready to eat food (Meat pie) in Benin City metropolis, Nigeria. Afr J Microbiol Resour 3: 390-395.
Davin-Regli A, Pagès JM. 2015. Enterobacter aerogenes and Enterobacter cloacae; versatile bacterial pathogens confronting antibiotic treatment. Front Microbiol 6: 1-10.

Edlin R, Shapiro D, Hersh A, Copp H.2013. Antibiotic resistance patterns in outpatient pediatric urinary tract infections. J Urol 190: 222-227.

Gardini F, Ozogul Y, Suzzi G, Tabanelli G, Ozogul F. 2016. Technical factors affecting biogenic amine content in foods: A Review. Front Microbiol 7: 1-18.

Gevers D, Huys G, Swings J. 2001. Applicability of rep-PCR fingerprinting for identification of Lactobacillus species. FEMS Microbiol Lett 205: 31-36.

Karlowsky J, Adam H, Desjardins M, Lagacé-Wiens P, Hoban D. 2013. Changes in fluoroquinolone resistance over 5 years (CANWARD 2007-11) in bacterial pathogens isolated in Canadian hospitals. J Antimicrob Chemother 68: i39-i46.

Koffi-Nevry R, Koussemon M. 2012. Microbiological composition, processing and consumer's characteristics of adjuevan, a traditional Ivorian fermented fish. Tropicultura 30: 241-250.

Lavefve L, Marasini D, Carbonero F. 2019. Microbial ecology of fermented vegetables and non-alcoholic drinks and current knowledge on their impact on human health. In: Toldra F (eds) Advances in Food and Nutrition Research. Academic Press, United Kingdom.

Lee CJD, McMullan PE, O'Kane CJ, Stevenson A, Santos IC, Roy C, Ghosh W, Mancinelli RL, Mormile MR, McMullan G, Banciu HL, Fares MA, Benison KC, Oren A, Dyall-Smith ML, Hallsworth JE. 2018. NaCl-saturated brines are thermodynamically moderate, rather than extreme, microbial habitats. FEMS Microbiol Rev 42: 672-693.

Li K, Lin K, Li Z, Zhang Q, Song F, Che Z, Chen G, Xiang W. 2014. Spoilage and pathogenic bacteria associated with spoilage process of Sichuan pickle during spontaneous fermentation. Food Sci Technol Res 20: 899-904.

Marino M, Maifreni M, Moret S, Rondinini G, 2000. The capacity of Enterobacteriaceae species to produce biogenic amines in cheese. Lett Appl Microbiol 31: 169-173

Medina E, Castro A, Romero C, Ramirez EM, Brenes M. 2015. Safety of fermented fruits and vegetables. In: Prakash V, Belloso O M, Keener L, Astley S B, Braun S, McMahon H, Lelieveld H (eds) Regulating Safety of Traditional and Ethnic Foods 1st Edition. Academic Press, United Kingdom.

Membre JM, Burlot PM. 1994. Effects of temperature, $\mathrm{pH}$, and $\mathrm{NaCl}$ on growth and pectinolytic activity of Pseudomonas marginalis. Appl Environ Microbiol 60: 2017-2022.

Motarjemi Y, Moy GG, Jooste PJ, Anelich LE. 2014. Milk and Dairy Products. In: Motarjemi Y, Lelieveld H (eds.). Food Safety Management: A Practical Guide for the Food Industry. Academic Press, United Kingdom

Munez E, Ramos A, Alvarez de Espejo T, Vaque J, Sanchez-Paya J. 2012. Aetiology of surgical infections in patients undergoing craniotomy. Neurocirugia (Astur) 23: 54-59.

Mustopa AZ. 2013. Isolation and Characterization of Lactobacillus plantarum S34 from Indonesian Traditional Food. [Dissertation] Dankook University, Seoul. [South Korea]

Mwizerwa H, Abong GO, Mbugua MWO, Gackheru P, Muiru M, Obura B, Viljoen B. 2018. Profiling of microbial content and growth in fermented maize-based products from Western Kenya. Curr Res Nutr Food Sci 6: 509-519.

Rahman HS, Othman HH. 2017. Salmonella Infection: the common cause of human food poisoning. Prog Biosci Bioeng 1: 5-10.

Ramzi YI. 2016. Pengaruh Lama Fermentasi Terhadap Mutu Masin Udang Rebon (Mysis relicta). [Skripsi]. Universitas Mataram, Mataram. [Indonesian]

Sherman JM, Holm GE, Albus WR. 1922. Salt effect in bacterial growth. J Bacteriol 7: 583-588.

Tamang JP, Shin DH, Jung SJ, Chae SW. 2016. Functional properties of microorganisms in fermented foods. Front Microbiol 7: 1-13.

Tamang JP, Watanabe K, Holzapfel WH. 2016. Review: Diversity of microorganisms in gloLAB fermented foods and beverages. Front Microbiol 7: 1-28.

Wu S, Xu S, Chen X, Sun H, Hu M, Bai Z, Zhuang G, Zhuang X. 2018. Bacterial communities changes during food waste spoilage. Sci Rep 8 (1): 8220-8228. 